\title{
PERFORMANCE ASSESSMENT OF REGIONAL WORKING UNIT IN THE MUNICIPALITY OF BULUNGAN, NORTH KALIMANTAN, INDONESIA
}

\author{
Setyowati Endah \\ Faculty of Administrative Science, University of Brawijaya, Indonesia \\ E-mail: endah71@gmail.com
}

\begin{abstract}
Performance assessment for each regional working unit is pivotal in order to increase quality and accountability of an organization. Regional government should carry out development programs of which orientation is the public interest. Therefore, public welfare should become the objective of regional development and consideration prior to establishment of government regulations about government affairs and authority. Even though it is not the only factor to determine quality of government performance, structure of an organization is an inseparable part of the foundation for developing government performance. A good structure of organization will certainly facilitate implementation of organizational activities. The objective of the study was to describe how far the government staffs implemented the main tasks and functions they were responsible for based on the performance assessment of each Regional Working Unit.
\end{abstract}

\section{KEY WORDS}

Performance assessment, regional government, organization, public interests.

The concept of performance is usually interpreted as the execution of fulfillment of duty. To determine the level of performance, performance assessment that refers to a process of recording and evaluating implementation of work within organization is a requirement. Performance assessment is an instrument for management (head of region and Regional Working Unit) to improve quality of decision-making and also accountability in the implementation of program and activities of an organization. Therefore, performance assessment is very important to do. Not only is performance of government officers related to implementation of a program or an agenda, but it also emphasizes on the result of the program/ agenda. Bernardin and Russell (1993) stated that performance was the result of function of task or activity carried out over a period of time. However, meeting the required result may become an issue the human resource (government officers) is unable to execute the task or activities well. In addition, the mindset and cultureset that the success of government performance is measured only by the government ability to spend the budget instead of how effective the budget is spent contribute to government's failure in executing the development plan.

Restructuring regional working unit answers the consequences/ changes the regional autonomy brings; the vision of the regional autonomy is creativity and willingness to realize good governance, the one capable of providing optimal service to the public. At the same time, the public has become more critical in addressing the phenomenon taking place in the region where they live due to increasing knowledge and insight they have. Public service is government sector the public pays close attention; they criticized complex hierarchical chain within the regional government working unit organization of local government which prevents faster, better and cheaper public service. Regional government should be able to execute effective, efficient, and economical governance. Public welfare should become the objective of regional development and consideration prior to establishment of government regulations about government affairs and authority. Even though it is not the only factor to determine quality of government performance, structure of an organization is an inseparable part of the foundation for developing government performance.

Assessment of which result becomes reference for improvement is vital in order to increase performance of the regional government. The assessment is an evaluation to 
assess condition and implementation of good governance. The objective is to create learning process that develops regional working unit further and alternative form to evaluate accountability of the regional working unit. Some of the dimensions in evaluation of organizational design and structure are the dimensions of complexity, formalization and centralization. Complexity is represented by hierarchical authority and responsibility, formalization refers to regulation represented by a set of formal, default rules and centralization is decision-making process, whether one is made by the central government or not. Instead of solution, performance assessment is a really useful tool. Theoretically and practically, the performance assessment can be useful to (1) help solving problem and its causes, (2) suggest most likely solution to the problem, (3) raise questions about principles and strategies, (4) encourage reflection on which following steps to make and how to get there, (5) provide information and ideas, (6) encourage follow-up on the information and ideas; (7) increase possibility for the positive change.

Evaluation as assessment process of which result may function as feedback that improves structure of an institution. Thus, follow-up is needed having completed the evaluation. Evaluation should involve all internal stakeholders (the structural, functional, and organizational staffs).

Therefore, it is critical to evaluate the regional government and regional working unit in order to develop one with the ability to run principles of good governance, and find out to what extent to the government employees carry out the main tasks and functions («TUPOKSI») as stated normatively. For that reason, the government of Bulungan Municipality, North Kalimantan should conduct performance assessment on their Regional Working Unit in order to provide service excellence and successfully realize public welfare.

\section{LITERATURE REVIEW}

Regional Government. Regional government basically has two roles, namely as the institution that provides service provider institution and as a political institution; integration between the two is needed to carry out both roles. In providing public services, the regional government ought to know and understand public interest, and pay attention to public aspirations. Regional government administration in general can be interpreted as the implementation of government role as institution that provides service and as a political institution. The executives and legislatives are the integration of the two roles the regional government has.

Administration of government administration has to be based on the basic principles, patterns of attitudes and patterns of democratic administration, as well as be objective and professional in creating justice and legal certainty. Culligan (as cited in Wasistiono, 2003) reiterated that the dramatic change strategy from the current administrative processes can actually be separated from its past roots. There is a relatively fixed basis in each of these changes, including division of functions. In every activity, there is planning, organizing, implementation and supervising functions.

Regional Government Conception in Regional Autonomy Framework. Regional autonomy refers to autonomous rights, authority and responsibility of a region to manage and maintain their own government affairs and needs of the locals ...» Autonomous region, which later is called region, is a legal entity which has territorial boundaries authorized to administer and and manage government affairs and the interests of the local community, according to its own initiative based on community aspirations in the state system. The policy on decentralization essentially has the main objectives, political and administrative objectives. Political objectives aim at giving room for the public for participating in government program, accountability, transparency and democracy. On the other side, the regional democratization aspect positions the regional government as medium of political education for the community at the local level. It is expected that regions will aggregately have significant contribution to development of national political education, and realization of civil society. On the other hand, the administrative objectives position the regional government as a service unit close to the community that are expected to function optimally in providing public services 
effectively, efficiently and economically to improve welfare of the local communities.

Evaluation Concept. Kumanto (2001) stated that «evaluation referred to assessment towards data gathered to various assessment methods.» Yunanda (2009) mentioned that «evaluation was well-planned activities to measure condition of an object using certain instrument and the result was contrasted to a set of standard before conclusion was drawn.» Using the definitions as reference, in general, it is assumed that evaluation is assessment activities through scientific measurement procedures with expectation that the result becomes instrument of consideration in objective and rational decision making to avoid repetition of errors that happened previously.

Furthermore, evaluation can be divided into two, namely:

1. Performance Evaluation. Payman J. Simanjuntak (2005) stated that «performance evaluation was assessing an individual, group, working unit in an organization or company using standardized performance or objective once established».

2. Policy and Program Evaluation. Policy evaluation is an activity that involves estimation or assessment of policies that includes substance, implementation and impact. Evaluation is considered as functional activity. That is not only is policy evaluation conducted at the final stages, but it also is conducted in the whole process of the policy» Dunn (1995) explained that «policy evaluation was a process to assess the results or performance of policies that had been establised».

In general, it can be assumed that evaluation is an important instrument in management or management of an organization due to its ability to guarantee sustainable development of the capacity, consistency and progressof performance or development of an organization.

Performance Assessment. Performance assesment is an important step in the human resource development cycle, both in public and the private sector. It is process of measuring the degree of completion of tasks performed by employees over a period of time. Result of the performance assesment serves as the basis of decision-making regarding payroll, promotion, dismissal, transfer and other employment decisions. Similarly, according to Suprihanto (1987), assessment of job performance / apprasial of perfomance was a system used to assess and know whether an employee had completed his or her responsibility as a whole or process that occurred within the organization in assessing and identifying performance of the employee.

A valid performance assesment is based on the following basic principles, namely:

- Fairness, performance assesment should reflect fairness for all employees involved in the process. Employees with good performance should get high scores and vice-versa;

- Transparency, performamnce assesment should be transparent in terms that all employees involved in the process can access their scores, reasons they get the scores and so on. Transparency will eliminate misuse of information;

- Independence, performance assesment conducted in certain year should not depend upon that conducted in the previous years;

- Empowerement, performance assessment should encourage and motivate employees in which well-motivated employees will facilitate and raise motivation of ill-motivated employees;

- No discrimination, performance assessment should not categorize employees based on their ethnic groups, nationalities, religion, home country, etc;

- Competitiveness, performance assessment should encourage employees to get involved in fair competition to increase their performance.

Assesment method has been developed to get objective, valid result. The system is mentoned as follow:

- Ranking, it is the simplest performance assesment system in which assessor compares performance between an employee and another to determine which one has better performance. The system has several drawbacks because conducting thorough assesement (experience, condition and knowledge) has always been a challenge; 
- Comparison between an employee to another in which evaluation towards an employee is divided into factors using the comparison between an employee to another. The factors refer to leadership, innitiative and job motivation. When scores of an employee is higher than those of another one, he or she has good performance.

- Grading, performance assessment is categorized into excellent, very good, good, fair, poor and very poor. The category may use distribution evaluation or level of categories so that the most preferable assessment is the most relative one among the employees;

- Graphic scale is the most frequently used traditional method in which an employeeis evaluated based on the factors that are considered the most important ones in the implementation of job description, for example quantity and quality of work and attitudes. These factors are divided into specific categories for example very good, fair, and poor and some descriptions for each factor and each category are provided. Selecting the factors used in the assessment is very difficult and requires the development of management in a careful manner;

- Checklist, instead of evaluation, assessors write down reports. Human Resource Department makes reports towards performance or behavior of an employee. Performance evaluation refers to an activity to decide to what extent the employee carries out his or her responsibility effectively.

\section{METHODS OF RESEARCH}

Based on the Program/Job Reference developed by employer and taking time and resources involved, the researcher developed a chart related to program/ job composition. Figure 1 described implementation of program/ job composition.

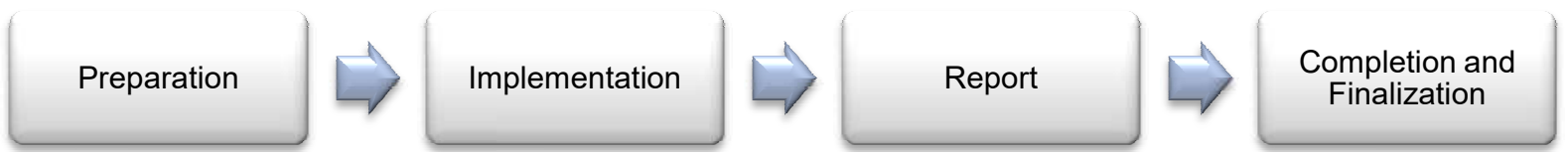

Figure 1 - Implementation of Program/ Job Composition

Preparation. Preparation was the first stage of the study. The purpose was to match perceptions about the implementation of the study as well as make sure all preparations had been made. The steps in the preparation stage were as follow:

- Mobilization of Experts;

- Theoretical Framework;

- Identifying Type of Data and Explaining Job Description of the Experts;

- Developing proposal: describing the background, purpose and target of the study, selecting approach and methods, developing performance management, making timetable (which agenda to conduct at what time);

- Preliminary Report, technical description of the proposal which involved the final paper assignment and method of analysis used.

Implementation. Implementation was the core of the study. The steps in the implementation stage were as follow:

- Data collection process (questionnaire was distributed to all Regional Working Units in Bulungan);

- Conducting theoretical analysis related to the focus of the study;

- Conducting studies and analysis twoards the current condition in Bulungan;

- Conducting analysis towards the Regional Working Units in Bulungan.

Report. Reporting was the follow-up of the implementation. It involves analysis (using the final analysis as reference to draw conclusion), drawing conclusions and giving suggestions or recommendations based on the findings of the study. The steps in the reporting stage were:

- Compiling analysis results from the experts; 
- Conducting thorough discussions between the experts;

- Describing the findings and discussions as a part of the final paper;

- Conducting Focus Group Discussion with various interest groups.

Completion and Finalization. Completion and finalization was the last stage of the study. It involves the following stage:

- Making revision based on the result of the Focus Group Discussion;

- Finalizing and submitting the final paper.

There are 48 Regional Working Units in the municipality. The questionnaires were distributed to all of them but 10 Regional Working Units did not fill them out (See appendix). From 38 Regional Working Units that completed the questionnaires, there were 34 Regional Working Units of which questionnaires were analyzed. The Regional Working Units consisted of 14 (fourteen) regional departments; 13 (thirteen) regional technical agencies, 4 (four) districts, 2 (two) sub-districts and one (one) inspectorate. On the other hands, 4 working units of which questionnaires could not be involved in the data analysis consisted of 1 (one) regional department, 1 (one) regional technical agency, 1 (one) district and 1 (one) government staff corps secretariat.

\section{RESULTS AND DISCUSSION}

There were 5 (five) Regional Working Units of which performance was categorized as very good, 15 (fifteen) Regional Working Units of which performance was categorized good, 9 (nine) Regional Working Units of which performance was categorized as fair and 5 (five) Regional Working Units of which performance was categorized as poor.

Based on the analysis, there were several sub-items the regional working units could not fulfill. One of the sub-items was the main tasks and functions. In general, the Regional Working Units found it challenging to meet the requirements for Pact of Integrity, one of the sub-aspects of the main tasks and functions.

In terms of human resources, the regional working units, in general, had yet been to fulfill the Development of Employee and Adherence towards the Law and Regulation that referred to employee taking a leave for continuing his or her study for more than 6 months will no longer receive position/ higher-level duties allowance or any other types of allowance starting from the seventh month until he or she graduated and got back to work.

The third aspect was financial. There were several sub-aspects the Regional Working Units could not fulfill. The first sub-aspect was Implementation and Administration of Financial Statement by the Regional Working Unit. It involved accuracy of imposition towards transaction on local tax revenue, local retribution, compensation on regional loss and others in the current year and those taking place in the previous years. The second sub-item was no salary had yet been taken for three months or more. When it did, things had been taken care of. The sub-item was one of the sub-aspects in Employee Expenses Document. The third sub-item was travelling abroad for work; it was one of the sub-aspects of Goods and Service Expenditure Documents. The sub-item had been executed well.

Conclusion. In general, the regional working units had yet performed satisfactorily in Procurement Procedure of Goods/Services, more particularly in the sub-item stating that no officer concurrently assigned as committee/officer responsible for procurement of goods and service or one responsible for inspecting them. It meant in general the regional working units could either determine and/or prove evidence that the sub-item existed in the real working condition.

\section{REFERENCES}

1. Arikunto, Suharsimi. 2004. prosedur penelitian suatu pendekatan praktek. Jakarta: Rineka Cipta

2. Bernardin, H. John \& Joyce E. A. Russel. 1993. Human Resource Management. Singapore: McGraw Hill Inc. 
3. Dunn, William. N. 1995. Analisis Kebijakan Publik. Yogyakarta: Gadjah Mada University Press

4. Griffin,P and Nix.P. 1991. Educational assessments and reporting. Sidney: Harcout Brace Javanovich, Publisher

5. Kumanto, Y. 2001. Authentic Assessment and Portfolio ssessment-Its Theory and Practice. Japan:Shizuoka University

6. Lababa, Djunaidi. 2008. Evaluasi Program: sebuah pengantar. http:///evaluasiprogram.html

7. Mangkunegara, A .A. Anwar Prabu .2005. Evaluasi Kinerja SDM. Bnadung: Refika Aditama

8. Payman J. Simanjuntak .2005. manajemen dan evaluasi kinerja. Jakarta: Faculty of Economics, University of Indonesia

9. Robinson, Bernadette. 2002. The CIPP approach to evaluation. COLLIT project.

10. Suprihanto, John.1987. Manajemen Personalia. Yogyakarta: BPFE

11. Wasistiono, Sadu.2003. Kapita Selekta Manajemen Pemerintahan Daerah. Bandung: CV Fokusmedia

12. Winarno. 2012. Kebijakan publik, Teori, Proses, Studi Kasus, Edisi dan Revisi Terbaru. Yogyakarta: CAPS

13. Wirawan. 2009. Evaluasi Kinerja Sumber Daya Manusia Teori Aplikasi dan Penelitian. Jakarta: Salemba Empat

14. Yunanda (2009). Evaluasi Program. Jakarta: Balai Pustaka

\section{APPENDIX}

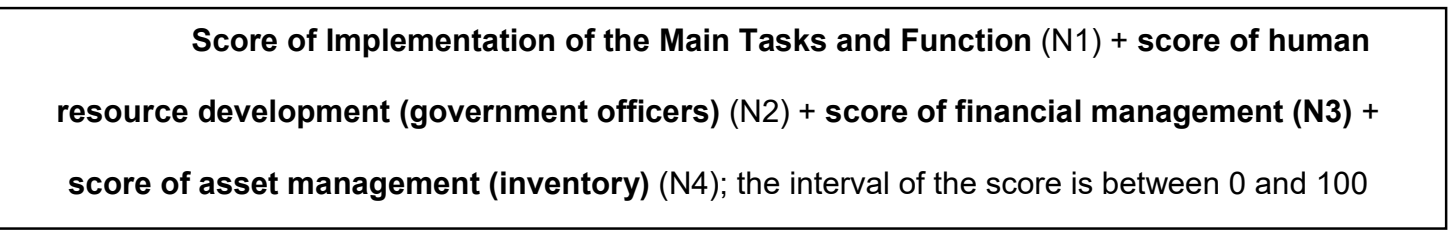

Figure 1 - Performance Assessment of the Regional Working Unit

Table 1 - Performance Assessment Criteria

\begin{tabular}{|c|c|c|}
\hline No & Performance Assessment Criteria & Score \\
\hline 1. & Very Good & $90-100$ \\
\hline 2. & Good & $75-89$ \\
\hline 3. & Fair & $51-74$ \\
\hline 4. & Fair & $\leq 50$ \\
\hline
\end{tabular}

Table 2 - Regional Working Unit in Bulungan Municipality

\begin{tabular}{|c|l|}
\hline № & \multicolumn{1}{|c|}{ Regional Working Unit } \\
\hline 1 & Department of Education \\
\hline 2 & Department of Public Health \\
\hline 3 & Dr. Soemarmo Sosroatmodjo Public Hospital \\
\hline 4 & Department of Public Work \\
\hline 5 & Regional Planning and Development Agency \\
\hline 6 & Department of Transportation \\
\hline 7 & Environmental Agency \\
\hline 8 & Department of Sanitation, Gardening, Funeral Service and Firework \\
\hline 9 & Department of Population and Civil Registration \\
\hline 10 & Agency of Woman Empowerment, Child Protection and Family Planning \\
\hline 11 & Department of Social Affairs \\
\hline 12 & Department of Labor and Transmigration \\
\hline 13 & Office of Unitary Nations and Community Protection \\
\hline 14 & Office of Civil Service and Community Protection \\
\hline 15 & Department of Mining and Energy \\
\hline 16 & Department of Culture, Tourism, Youth and Sports \\
\hline
\end{tabular}




\begin{tabular}{|l|l|}
\hline \multicolumn{2}{|c|}{ Continue of Table 2} \\
\hline 17 & Department of Fisheries and Marine Affairs \\
\hline 18 & Department of Industry, Trading, Cooperatives and SMEs \\
\hline 19 & Agriculture and Food Security Agency \\
\hline 20 & Office of Education and Training \\
\hline 21 & Regional Disaster Relief Agency \\
\hline 22 & Regional Financial Management and Asset Agency \\
\hline 23 & Regional Civil Service Agency \\
\hline 24 & Inspectorate \\
\hline 25 & Investment and License Agency \\
\hline 26 & Local Community and Village Empowerment Agency \\
\hline 27 & Office of Library and Archives \\
\hline 28 & Department of Agriculture \\
\hline 29 & Department of Forestry \\
\hline 30 & Local Revenue Offices \\
\hline 31 & Tanjung Selor District \\
\hline 32 & Tanjung Palas District \\
\hline 33 & Tanjung Palas Barat District \\
\hline 34 & Tanjung Palas Timur District \\
\hline 35 & Tanjung Palas Tengah District \\
\hline 36 & Tanjung Palas Utara District \\
\hline 37 & Peso District \\
\hline 38 & Peso Hilir District \\
\hline 39 & Sekatak District \\
\hline 40 & Bunyu District \\
\hline 41 & Tanjung Selor Ulu Sub-district \\
\hline 42 & Tanjung Selor Hilir Sub-district \\
\hline 43 & Tanjung Selor Timur Sub-district \\
\hline 44 & Tanjung Palas Hilir Sub-district \\
\hline 45 & Tanjung Palas Hulu Sub-district \\
\hline 46 & Tanjung Palas Tengah Sub-district \\
\hline 47 & Karang Anyar Sub-district \\
\hline 48 & Government Officer Corps Secretariat \\
\hline
\end{tabular}

Table 3 - Regional Working Units that Did not Fill Out the Questionnaire

\begin{tabular}{|c|l|}
\hline № & \multicolumn{1}{c|}{ Regional Working Units that Did not Fill Out the Questionnaire } \\
\hline 1 & Tanjung Palas District \\
\hline 2 & Tanjung Palas Barat District \\
\hline 3 & Tanjung Palas Timur District \\
\hline 4 & Tanjung Palas Utara District \\
\hline 5 & Sekatak District \\
\hline 6 & Bunyu District \\
\hline 7 & Tanjung Selor Ulu Sub-district \\
\hline 8 & Tanjung Selor Timur Sub-district \\
\hline 9 & Tanjung Palas Hilir Sub-district \\
\hline 10 & Tanjung Palas Tengah Sub-district \\
\hline
\end{tabular}

Table 4 - Performance Assesment Tabulation

\begin{tabular}{|c|l|l|l|}
\hline № & \multicolumn{1}{|c|}{ Regional Working Unit } & \multicolumn{1}{c|}{ Result } & \multicolumn{1}{c|}{ Description } \\
\hline 1 & $\begin{array}{l}\text { REGIONAL CIVIL SERVICE } \\
\text { AGENCY }\end{array}$ & Tabulated & Incomplete Supporting Documents \\
\hline 2 & ENVIRONMENTAL AGENCY & Tabulated & Complete Supporting Document \\
\hline 3 & $\begin{array}{l}\text { LOCAL COMMUNITY AND VILLAGE } \\
\text { EMPOWEREMENT AGENCY }\end{array}$ & Tabulated & Incomplete Supporting Documents \\
\hline 4 & $\begin{array}{l}\text { WOMAN EMPOWEREMENT, CHILD } \\
\text { PROTECTION AND FAMILY } \\
\text { PLANNING AGENCY }\end{array}$ & $\begin{array}{l}\text { Tabulated } \\
\text { AGESTMENT AND LICENSE }\end{array}$ & Sufficient Number of Supporting Documents \\
\hline 6 & $\begin{array}{l}\text { REGIONAL DISASTER RELIEF } \\
\text { AGENCY }\end{array}$ & Tabulated & Complete Supporting Document \\
\hline
\end{tabular}




\begin{tabular}{|c|c|c|c|}
\hline 7 & \begin{tabular}{|l} 
REGIONAL FINANCIAL \\
MANAGEMENT AND ASSET \\
AGENCY \\
\end{tabular} & Tabulated & Sufficient Number of Supporting Documents \\
\hline 8 & $\begin{array}{l}\text { AGRICULTURE AND FOOD } \\
\text { SECURITY AGENCY }\end{array}$ & Tabulated & Sufficient Number of Supporting Documents \\
\hline 9 & $\begin{array}{l}\text { REGIONAL PLANNING AND } \\
\text { DEVELOPMENT AGENCY } \\
\end{array}$ & Tabulated & Sufficient Number of Supporting Documents \\
\hline 10 & $\begin{array}{l}\text { DR. SOEMARMO SOSROATMODJO } \\
\text { PUBLIC HOSPITAL }\end{array}$ & Tabulated & Sufficient Number of Supporting Documents \\
\hline 11 & $\begin{array}{l}\text { DEPARTMENT OF HYGIENE, } \\
\text { GARDENING, FUNERAL AFFAIR } \\
\text { AND FIREWORK } \\
\end{array}$ & Tabulated & Sufficient Number of Supporting Documents \\
\hline 12 & $\begin{array}{l}\text { DEPARTMENT OF CULTURE, } \\
\text { TOURISM, YOUTH AND SPORTS } \\
\end{array}$ & Tabulated & Sufficient Number of Supporting Documents \\
\hline 13 & DEPARTMENT OF FORESTRY & $\begin{array}{l}\text { Cannot be } \\
\text { Tabulated }\end{array}$ & No Supporting Document \\
\hline 14 & $\begin{array}{l}\text { DEPARTMENT OF POPULATION } \\
\text { AND CIVIL REGISTRATION }\end{array}$ & Tabulated & Incomplete Supporting Document \\
\hline 15 & DEPARTMENT OF PUBLIC HEALTH & Tabulated & Incomplete Supporting Document \\
\hline 16 & DEPARTMENT OF PUBLIC WORKS & Tabulated & Incomplete Supporting Document \\
\hline 17 & LOCAL REVENUE OFFICES & Tabulated & Sufficient Number of Supporting Documents \\
\hline 18 & DEPARTMENT OF EDUCATION & Tabulated & Complete Supporting Document \\
\hline 19 & \begin{tabular}{|l|} 
DEPARTMENT OF \\
TRANSPORTATION \\
\end{tabular} & Tabulated & Sufficient Number of Supporting Documents \\
\hline 20 & $\begin{array}{l}\text { DEPARTMENT OF FISHERIES AND } \\
\text { MARINE AFFAIRS }\end{array}$ & Tabulated & Sufficient Number of Supporting Documents \\
\hline 21 & $\begin{array}{l}\text { DEPARTMENT OF INDUSTRY, } \\
\text { TRADING, COOPERATIVES AND } \\
\text { SMES } \\
\end{array}$ & Tabulated & Incomplete Supporting Documents \\
\hline 22 & $\begin{array}{l}\text { DEPARTMENT OF MINING AND } \\
\text { ENERGY }\end{array}$ & Tabulated & Sufficient Number of Supporting Documents \\
\hline 23 & DEPARTMENT OF AGRICULTURE & Tabulated & Sufficient Number of Supporting Documents \\
\hline 24 & $\begin{array}{l}\text { DEPARTMENT OF SOCIAL } \\
\text { AFFAIRS }\end{array}$ & Tabulated & Complete Supporting Document \\
\hline 25 & $\begin{array}{l}\text { DEPARTMENT OF LABOR AND } \\
\text { TRANSMIGRATION }\end{array}$ & Tabulated & Incomplete Supporting Document \\
\hline 26 & THE INSPECTORATE & Tabulated & Incomplete Supporting Document \\
\hline 27 & $\begin{array}{l}\text { OFFICE OF UNITARY NATIONS } \\
\text { AND PROTECTION OF THE } \\
\text { COMMUNITY }\end{array}$ & $\begin{array}{l}\text { Cannot be } \\
\text { Tabulated }\end{array}$ & No Supporting Document \\
\hline 28 & $\begin{array}{l}\text { OFFICE OF EDUCATION AND } \\
\text { TRAINING }\end{array}$ & Tabulated & Complete Supporting Document \\
\hline 29 & $\begin{array}{l}\text { OFFICE OF LIBRARY AND } \\
\text { ARCHIVES }\end{array}$ & Tabulated & Incomplete Supporting Documents \\
\hline 30 & $\begin{array}{l}\text { OFFICE OF CIVIL SERVICE AND } \\
\text { COMMUNITY PROTECTION }\end{array}$ & Tabulated & Sufficient Number of Supporting Documents \\
\hline 31 & PESO DISTRICT & Tabulated & Sufficient Number of Supporting Documents \\
\hline 32 & PESO HILIR DISTRICT & Tabulated & Sufficient Number of Supporting Documents \\
\hline 33 & $\begin{array}{l}\text { TANJUNG PALAS TENGAH } \\
\text { DISTRICT }\end{array}$ & Tabulated & Incomplete Supporting Documents \\
\hline 34 & TANJUNG SELOR DISTRICT & Tabulated & Incomplete Supporting Documents \\
\hline 35 & KARANG ANYAR DISTRICT & Tabulated & Incomplete Supporting Documents \\
\hline 36 & TANJUNG PALAS HULU DISTRICT & Tabulated & Incomplete Supporting Documents \\
\hline 37 & TANJUNG SELOR HILIR DISTRICT & $\begin{array}{l}\text { Cannot be } \\
\text { Tabulated }\end{array}$ & No Supporting Document \\
\hline 38 & $\begin{array}{l}\text { GOVERNMENT OFFICER CORPS } \\
\text { SECRETARIAT (NON-WORKING } \\
\text { UNIT) }\end{array}$ & $\begin{array}{l}\text { Cannot be } \\
\text { Tabulated }\end{array}$ & $\begin{array}{l}\text { Not a working unit (based on the } 2007 \text { Government } \\
\text { Regulation number 41) }\end{array}$ \\
\hline
\end{tabular}

